\title{
Australian court rules that passive smoking causes lung cancer, asthma attacks, and respiratory disease
}

\author{
Simon Chapman, Stephen Woodward
}

On 7 February 1991 Justice Trevor Morling of the federal court of Australia handed down a ruling on involuntary passive smoking. ${ }^{1}$ If upheld on appeal the Morling judgment will enter the history of modern public health as one of the major turning points in the worldwide efforts to reduce smoking related diseases.

The judgment concerned a case brought by the Australian Federation of Consumer Organisations against the Tobacco Institute of Australia over an advertisement lodged in 14 major Australian newspapers on 1 July 1986. The advertisement, headed "A message from those who do ... to those who don't," advanced the argument that "there is little evidence and nothing which proves scientifically that cigarette smoke causes disease in non-smokers." It argued that environmental tobacco smoke was basically an issue of "annoyance" and did not constitute a "health hazard" or "health risk." It cited three health agencies-the Institute of Cancer Research in the United Kingdom; the American Cancer Society; and the World Health Organisation -in ways that implied that these agencies also disputed the view that passive smoking was dangerous.

The publication of the advertisement seemed to be timed to mitigate the influence of two forthcoming events: the public release of the Australian National Health and Medical Research Council's report Effects of Passive Smoking on Health, which had been adopted in June $1986,{ }^{2}$ and a resolution to ban smoking on all public transport, including airlines, due to be debated at the Australian Labor party's biennial national conference, 7-11 July 1986. This resolution would have been seen as critical to the tobacco industry because the party's rules require it, when in government, to implement its platform. The Labor party was in power in 1986, so if this resolution was passed there was a strong likelihood that it would become government policy and pass into law. The government banned smoking on all passenger flights in Australia in 1987.

University of Sydney, Westmead Hospital 2145, Australia

Simon Chapman, PHD, senior lecturer in community medicine

Action on Smoking and Health, Surry Hills 2010 Australia

Stephen Woodward, BSC, executive director

Correspondence to: Dr Chapman.

BMF 1991;302:943-5

\section{Institute hounded for three years}

The federal court judgment brought to a head a concentrated three year campaign of hounding the tobacco institute over the advertisement. This campaign saw the institute humiliated on four occasions, with the final court ruling likely to set in motion what media commentators predict could be an avalanche of civil litigation. Immediately after the publication of the advertisement Dr Paul Magnus of the National Heart Foundation and Stephen Woodward of Action on Smoking and Health (ASH) contacted officials of the three agencies cited in the advertisement to determine whether the advertisement accurately reflected their research or policies. Officials from each agency duly replied in letters to the press, each strongly objecting

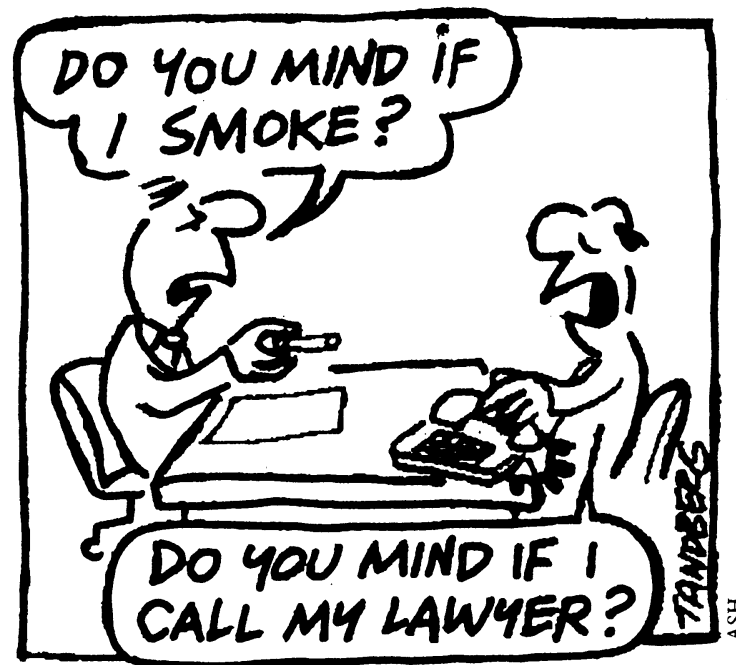

to the distortions and misrepresentations in the advertisement.

Then the Australian Council on Smoking and Health, a Western Australian based lobby group, complained about the advertisement to the advertising and media industries' self regulatory body, the Advertising Standards Council. The council, which has a long history of being attacked by public health interests as a less than impartial, industry stacked body, ${ }^{34}$ none the less upheld the council's complaint, with details being reported in the press on 20 October 1986. These little castigations were but nothing to what was to follow. Unbeknown to the main Australian smoking control lobby groups, the Australian Federation of Consumer Organisations had undertaken a different plan of action. The federation is the peak policy body of the consumer movement in Australia and several of its officials had attended the International Organisation of Consumers' Unions world congress in Bangkok the previous year. The congress marked the formal entry of the consumer movement into the tobacco control field, with delegates being urged to return home and apply the consumer movement's lobbying muscle and particular skills with business regulatory matters to a hitherto largely neglected foe for the consumer movement: the tobacco industry.

The decision of the Australian Federation of Consumer Organisations about an appropriate avenue for action over the advertisement was to prove astute. It took its complaint to the federal government's Trade Practices Commission, a body concerned with the administration of the Trade Practices Act, which prohibits, among other matters, misleading and deceptive advertising. After receiving the complaint the commission carried out an investigation but resolved the matter on the basis of an undertaking that 
the Tobacco Institute of Australia would not republish the advertisement and would publish a corrective advertisement in the same 14 newspapers, providing additional information "so the readers may judge the matter for themselves." Dissatisfied with this outcome, the federation sought an undertaking from the tobacco institute that it would never again use the words "there is little evidence and nothing which proves scientifically that cigarette smoke causes disease in non-smokers" or make any similar statement in any advertising or in any promotional material. The federation also required that the tobacco institute should not cite a study referred to in the advertisement as being "based on a wealth of statistical detail from a study involving 12000 people." The relevant subjects in the study had numbered about 700 .

The tobacco institute refused to give such an undertaking and so on 11 June 1987 the federation instituted proceedings in the Federal Court of Australia for an injunction to restrain the institute from making such statements. The institute challenged the federation's rights to bring these proceedings but failed in a ruling in 1988. The interlocutory skirmishes were over and a battle royal was about to start. Witnesses began to be called from 20 November 1988, with the court sitting for 90 days, including for a period in the United Kingdom. The consumers federation called such expert witnesses as Professor Tony McMichael (Adelaide), Professor Lou Landau (Western Australia), Professor Peter Phelan (Melbourne), Sir Richard Doll (Oxford), Professor Nick Wald (St Bartholomew's Hospital), Professor Dimitros Trichopoulos (Harvard), and Professor Dwight Janerich (Yale). The tobacco institute called statistical consultants, physicians, and toxicologists from Australia, the United States, Britain, and Sweden. By the end of proceedings on 25 September 1990 the institute had spent an estimated $\$$ A5 million in legal fees and witness expenses. The consumers federation received some legal aid from the Federal Minister for Justice and Consumer Affairs but the bulk of its expenses were borne by its counsel, solicitors, and witnesses, who deferred payment of fees and expenses as the litigation became increasingly protracted. Agencies which support research on heart disease and cancer also made important contributions.

Justice.Morling had presided over the royal commission into the death of baby Azaria Chamberlain at Ayer's Rock in central Australia. The commission resulted in the acquittal of the baby's mother and involved the evaluation of some of the most intricate and protracted scientific evidence ever to come before a court. The judge was thus experienced in evaluating complex scientific matters against legal considerations. Justice Morling's 211 page judgment reviews numerous epidemiological studies and five major reviews on passive smoking and assesses the evidence of 20 expert witnesses called by the federation and the Tobacco Institute of Australia.

\section{"Overwhelming evidence"}

Morling's conclusions included that "there is compelling scientific evidence that cigarette smoke causes lung cancer in non-smokers" ( $p$ 135). He found that "there is overwhelming evidence... that passive smoking causes some people to experience attacks of asthma" (p 196) and said that he could not "accept that the draftsman of the advertisement held an opinion to the contrary. No rational basis exists for the holding of an opinion that there is little evidence and nothing which proves scientifically that cigarette smoke causes attacks of asthma" (p 199).

Of respiratory disease in young children he concluded:
In my opinion the only conclusion open on the evidence is that the statement that there was little evidence and nothing which proves scientifically that cigarette smoke causes disease in non-smokers was demonstrably false in 1986 in so far as it applied to respiratory disease in children in the first vear of life. The statement remains false to this day. In my view the falsity of the statement is demonstrated whatever meaning one gives to the terms "little evidence" and "scientific proof." I share the opinion expressed by Professor Phelan that the evidence establishing a causal relationship between passive smoking and respiratory disease in very young children is overwhelming. The evidence is of such strength that it constitutes scientific proof. The evidence is of two kinds, epidemiological and clinical. I cannot help observing that none of the witnesses called by the respondent were specialist paediatricians or epidemiologists. On the other hand, the applicant's witnesses included specialists in both these fields. I think that the respondent would have called specialists in these fields, of whom there must be many in this country and overseas, had they been able to give evidence favourable to the respondent's case (p 182).

Justice Morling noted that despite the resources of the international tobacco industry, the tobacco institute was unable to find even one epidemiologist who would testify in a manner contrary to the epidemiologists called by the federation:

The respondent failed to call one witness whose special expertise is in epidemiology and of whom it could be said that he "properly" held views contrary to those expressed by the distinguished epidemiologists called by the applicant. It is a fair assumption, I think, that such a witness would have been called by the respondent had he been available. In these circumstances, the concession [concerning the possibility of contrary assessments of the evidence] made [by epidemiological witnesses for the applicant] was little more than an admission of the theoretical possibility that another epidemiologist may hold contrary views, rather than a concession that any competent epidemiologist does in fact hold contrary views ( $\mathrm{p} 74$ ).

Justice Morling was almost uniformly critical of the tobacco institute's witnesses as being concerned to criticise only particular studies, whereas the federation's witnesses

Tended to regard the separate items of scientific material - for example, epidemiological studies, the "no threshold" for carcinogens theory, the presence of carcinogens in environmental tobacco smoke, and cotinine levels in non-smokersas constituent parts of a mosaic, each piece itself representing some evidence that environmental tobacco smoke causes cancer in non-smokers ( $\mathrm{p} 93$ )

\section{Witnesses criticised}

He described Professor Gary Huber (a professor of medicine in Texas) as "evasive," some of his answers "unsatisfactory," and said that he "did not find Professor Huber a satisfactory witness in all respects." He added that, "Of all the witnesses called by the respondent, I found him the least impressive" (pp 117-8). Of Dr Sven Malmfors, a consultant toxicologist called by the tobacco institute, Justice Morling said, "It seems to me that Dr Malmfors' requirements for the establishment of scientific truth are almost unobtainable" (p 119). Similarly, of emeritus Professor John Clayton (Arizona) he noted, "Professor Clayton is of the opinion that toxicology has not provided any proof that mainstream smoke causes lung cancer in active smokers" (122), and that Clayton was not prepared to concede that the International Agency for Research on Cancer's conclusions about the evidence of the carcinogenicity of various components of tobacco smoke were soundly based.

Justice Morling's most caustic remarks were perhaps reserved for a Californian consulting statistician, Dr Maxwell Layard of whom he wrote:

Plainly he has a very close association with the tobacco industry and depends on it for most of his income. . . I do not 
think that Dr Layard expressed opinions which he does not hold, but I do think his hypercritical approach to the epidemiological studies may not be disassociated with his close connection with the tobacco industry (p 100).

The implications of the Morling judgment are likely to be profound. Directors of state cancer councils around Australia report that they have been inundated with inquiries concerning potential civil actions against employers who have so far refused to implement smoke free workplaces. Since 1985 there have been eight workers' compensation cases involving monetary payouts to workers claiming severe discomfort or disease arising from involuntary, passive smoking. ${ }^{6}$ In the most publicised of these an out of court settlement of $\$ A 65000$ was made by a transport employer to a bus driver employee, Sean Carroll, with lung cancer after legal argument that his years of exposure to environmental tobacco smoke had caused the lung cancer. The decision was reported widely in the Australian press as a likely precedent that would precipitate the introduction of smoking bans in workplaces by employers anxious to avoid illness compensation litigation. Mr Carroll died on 25 January, 14 days before the Morling judgment.

A recent survey by the National Heart Foundation in New South Wales of that state's top 232 private and public sector companies found that $56 \%$ have introduced smoke free workplaces, $47 \%$ in the past year (unpublished data). This trend has almost certainly been motivated by management concerns about possible litigation. In 1986 the Australian Attorney General said in the Australian parliament, "injury from passive smoking is reasonably foreseeable and... consequently such an injury could give rise to an action for damages at common law."

In 1978 the Roper report to the United States Tobacco Institute declared of the passive smoking issue, "This we see as the most dangerous development to the viability of the tobacco industry that has yet occurred" and suggested that, "The strategic and long run antidote to the passive smoking issue is ... developing and widely publicizing clear-cut, credible, medical evidence that passive smoking is not harmful to the non-smoker's health." The advertisement by the Tobacco Institute of Australia was surely a product of such thinking and the Morling judgment has probably dealt a death blow to any industry's hopes of further applications of the Roper "antidote."

\section{Trojan horse effect}

Why did the tobacco industry decide to fight this expensive case till the end? We believe the most obvious, but strangely underanalysed answer lies in the
Trojan horse effect of passive smoking restrictions on sales resulting from reduced smoking opportunities when smoking is restricted. ${ }^{10}$ For example, a study of the impact of the 1988 introduction of a total ban on smoking in Australian public service buildings found that, six months after the ban, the average smoker reduced his or her smoking over a 24 hour period by $5 \cdot 18$ cigarettes. ${ }^{11}$ Heavy smokers reduced by $7 \cdot 9$ cigarettes, a $26.6 \%$ decrease. It was calculated that if half of office workplaces introduced such policies in the next five years, 654880000 cigarettes would be forgone in one year. At $\$ \mathrm{~A} 0.10$ a cigarette, this would represent an annual amount of $\$ A 6548800$ at 1988 prices lost in retail cigarette sales. The rate of adoption of smoking bans at work was found to be much higher than that in the National Heart Foundation study referred to above. Extrapolated world wide, the advance of restrictions on smoking in enclosed spaces will cost the industry hundreds of millions of dollars.

In 1978, the same year as the Roper report warnings to the American tobacco industry, William Hobbs, a president of the tobacco multinational RJ Reynolds said about antismoking measures "If they caused every smoker to smoke just one less cigarette a day, our company would stand to lose $\$ 92$ million in sales annually. I assure you that we don't intend to let that happen without a fight." After the Morling judgment the odds on public health winning such a fight have improved mightily.

Copies of the Morling judgment are available from Action on Smoking and Health, 5th Floor, 64 Kippax Street, Surry Hills 2010, Australia.

1 Australian Federation of Consumer Organisations Incorporated $v$ Tobacco Institute of Australia. Federal Court of Australia No NG 253 [1987]. Judgment by Justice Trevor Morling, 7 February 1991.

2 National Health and Medical Research Council. Effects of passive smoking on health. Canberra: Australian Government Publishing Service. 1987

3 Chapman S. A David and Goliath story: tobacco advertising in Australia. BMf 1980;281:1187-90.

4 Chapman S, Mackay B. Good for the goose, good for the gander: complaints and judgments about smoking and anti-smoking advertisements under advertising self regulation. Media Information Australia 1984;31:47-54.

5 Lee PN, Chamberlain J, Alderson MR. Relationship of passive smoking to risk of lung cancer and other smoking-associated diseases. Br f Cancer 1986;54: 97-105.

6 Winstanlev M. Tobacco in Australia. Facts and issues. Surry Hills: Action on Smoking and Health (Australia), 1989.

7 Woodward SD, Winstanley MH. Lung cancer and passive smoking at work: the Carroll case. Med J A ust 1990;153:682-4.

8 House of Representatives. Hansard 1986, November 13. Advice from the attorney general. (No 2979.

9 Roper Organization Incorporated. A study of public attitudes toward cigarette smoking and the tobacco industry. Volume 1. United States: Roper Organization Incorporated, 1978

10 Chapman S, Borland R, Hill D, Owen N, Woodward S. Why the tobacco industry fears the passive smoking issue. Int f Health Serv 1990;20:417-27.

11 Borland R, Chapman S, Owen N, Hill D. Effects of workplace bans on cigarette consumption. A f Public Health 1990;80 (2): 178-80.

(Accepted 27 February 1991)

\section{ANY QUESTIONS}

A patient had an expulsive haemorrhage after a cataract operation on one eye. What is the risk of a similar complication if a cataract is removed from the other eye?

Expulsive choroidal haemorrhage is one of the most feared and devastating complications of all types of intraocular surgery, its incidence after cataract surgery ranging from $0.05 \%$ to $0.4 \%$.' In reported series only about $12 \%$ of eyes retain any vision and in these vision is $6 / 60$ at best after vitreoretinal surgery and high dose systemic steroids. Lesser degrees of choroidal haemorrhage or effusion may occur without such a severe visual prognosis.

The risk factors are hypertension, arteriosclerosis, glaucoma, myopia, and prolonged intraocular manipulation. Both surgeon and patient must be satisfied that surgery to the fellow eye is justified as it is usually attended by some of the same risk factors. Before cataract surgery systemic and ocular hypertension must be adequately controlled. I would favour general anaesthesia by an anaesthetist of my choice to ensure optimal intraocular operating conditions. Preplaced sutures should be used so that the eye can be rapidly closed, and suprachoroidal drainage incisions should be made before opening the anterior chamber; blood will thus be encouraged to escape the eye posteriorly rather than to cause prolapse of the choroid and retina through the cataract incision. By these manoeuvres successful surgery may be achieved for some of these unfortunate patients. ${ }^{2}$ - MICHAEL HAYWARD, consultant ophthalmic surgeon, Leeds General Infirmary

1 Taylor DM. Expulsive hemorrhage. Am f Ophthalmol 1974;78:961-6.

2 Lambrou FH Jr, Meredith TA, Kaplan HJ. Secondary surgical management of expulsive choroidal hemorrhage. Arch Ophthalmol 1987;105:1195-8.

3 Awan KJ. Intraccular lens implantation following expulsive choroidal hemorrhage. Am f Ophthalmol 1988;106:261-3. 